\title{
Laparoscopic management of the advanced and rectovaginal endometriosis with gastrointestinal involvement: A review of the current literature
}

\author{
Gastrointestinal tutulum olan ileri evre ve rektovajinal endometriozisin \\ laparoskopik yönetimi: Güncel literatürün bir derlemesi
}

Serkan Kahyaoğlu*

Department of Obstetrics and Gynecology, (S. Kahyaoğlu, MD), Zekai Tahir Burak Women's Health Education and Research Hospital, TR-06230 Ankara

\begin{abstract}
Endometriosis is the presence of endometrial gland and stromal tissue outside the uterus with a potentially invasive nature despite being a benign disease process. The exact prevalence of the disease is not known but $10-15 \%$ of reproductive age women are affected. The peritoneal and rectovaginal endometriosis are two distinct entities of the disease with different symptoms and treatment strategies. Dyschezia and deep dyspareunia with nodularity on sacrouterine ligaments during rectovaginal examination are specific symptoms of deeply infiltrating endometriosis (DIE). Rectovaginal or bowel involvement is estimated to be present in 5 to 12 percent of women with endometriosis and the most common site is the rectosigmoid colon. Medical treatment of DIE with colorectal involvement results with symptomatic relief without any curative effect on endometriotic foci. Colorectal endometriosis treatment is a major challenge for the clinicians when incidentally encountered during a diagnostic laparoscopy. As randomised controlled studies comparing medical with surgical treatment for rectovaginal or bowel endometriosis are lacking; the impact of the surgical treatment modalities on clinical improvement of the symptoms, complications, recurrence and pregnancy rates is not known. Current literature indicates that, patients without bowel occlusion and/ or rectal bleeding with mucosal involvement caused by DIE should be treated with conservative technique specifically described as "shaving" method that have lower complication and recurrence rates than the invasive technique including bowel resection and anastomosis.
\end{abstract}

Keywords: Laparoscopy, gastrointestinal, rectovaginal, bowel endometriosis, surgical treatment

\section{Özet}

Endometriozis iyi huylu bir hastalık prosesi olmasına rağmen endometrial gland ve stromanın uterus dışında potansiyel olarak invazif bir davranışla bulunmasıdır. Hastalığın kesin prevelansı bilinmemektedir fakat üreme çaındaki kadınların yaklaşı \%10-15'i etkilenmiştir. Peritoneal ve rektovajinal endometriozis hastalığın farklı semptom ve tedavi stratejileri olan iki ayrı antitesidir. Rektovajinal muayene sırasında sakrouterin ligamentlerde nodülarite ile beraber diskezi ve derin disparanü derin infiltratif endometriozisin (DİE) spesifik semptomlarıdır. Endometriozisli hastaların yaklaşık \%5-12'sinde rektovajinal veya barsak tutulumu mevcut olduğu tahmin edilmektedir ve en sık tutulan bölge rektosigmoid kolondur. Kolorektal tutumlu DíE'nin tıbbi tedavisi endometriotik odaklar üzerinde herhangi bir küratif etki etmeden semptomatik rahatlama sağlar. Tanısal bir laparoskopi sırasında tesadüfen saptandığında kolorektal endometriozis tedavisi klinisyenler için major bir sorundur. Rektovajinal veya barsak endometriozisinin medikal ve cerrahi tedavisini birbiri ile karşılaştıran randomize kontrollü çalışmalar olmadığı için cerrahi tedavi modalitelerinin semptomlarda klinik düzelme, komplikasyonlar, rekürrens ve gebelik oranları üzerine etkisi bilinememektedir. Güncel literatüre göre, barsak oklüzyonu ve/ veya rektal kanama olmadan mukozal tutulum olan DİE vakaları invazif bir teknik olan barsak rezeksiyonu ve anastomozundan daha düşük komplikasyon ve rekürrens oranlarına sahip olduğundan dolayı özel olarak "traşlama" adı verilen konservatif bir teknikle tedavi edilmelidirler.

Anahtar sözcükler: Laparoskopi, gastrointestinal, rektovajinal, barsak endmetriozisi, cerrahi tedavi 
Geliş tarihi/Received: December 01, 2014; Kabul tarihi/Accepted: June 03, 2014

\section{*Corresponding author:}

Dr. Serkan Kahyaoğlu, Kadın Hastalıkları ve Jinekoloji Anabilim Dalı, Zekai Tahir Burak Kadın Hastalıkları ve Doğum Hastanesi, TR-06230 Ankara. E-mail: mdserkankahyaoglu@ gmail.com

\section{Introduction}

Endometriosis is the presence of endometrial gland and stromal tissue outside the uterus with a potentially invasive nature despite being a benign disease process. The exact prevalence of the disease is not known but $10-15 \%$ of reproductive age women are affected. Chronic and cyclic pelvic pain, adnexal masses, pelvic adhesions and infertility are consequences of the disease. Medical therapy including combined oral contraceptives, progestins, GnRH analogs, aromatase inhibitors, danazol and levonorgestrel releasing intrauterine devices is the first choice for pelvic pain. Patients without pain relief from medical treatment and/or having ovarian endometriomas should be treated with conservative or definitive surgical treatment according to their desire for future fertility.

Donnez et al. [1] have first proposed the definition that described peritoneal and rectovaginal endometriosis as two distinct entities. They pointed that only $10 \%$ of the rectovaginal endometriosis cases result from metaplasia of the mullerian rests within the rectovaginal septum and majority of the cases stem from posterior part of the cervix. The lack of expression of HOX10 (related o the endometrium) gene expression within the deep retrocervical and rectovaginal endometriotic lesions proves that these lesions do not originate from infiltrating peritoneal endometriosis. Majority of the deep endometriotic lesions originate from retrocervical space as demonstrated by magnetic resonance imaging (MRI). The main component of the rectovaginal endometriosis is smooth muscle (90\% of the content) that is responsible fort he nodular shape of the lesion with an accompanying fibrosis. This nodular lesion exhibits low mitotic activity resulting with a relatively slw evolution of the nodule and weak response to hormonal therapeutic manipulation necessitating surgical excision as a definitive approach. Squifflet et al. [2] defined three types of deep retroperitoneal lesions according to their locations detected precisely by transrecal ultrasonography and MRI: (1) Type 1: Rectovaginal septum lesions (10\%), Type 2: Posterior vaginal fornix lesions (58\%) and Type 3: Hourglassshaped lesions $(32 \%)$. Surgical management of the patients with severe disease involving bowel, bladder, ureters, or pelvic nerves deserve is also indicated. Dyschezia and deep dyspareunia with nodularity on sacrouterine ligaments during rectovaginal examination are specific symptoms of deeply infiltrating endometriosis (DIE) of the bowel and rectovaginal septum. MRI is a useful diagnostic adjunct to detect the extent of the disease process involving rectovaginal septum and bowel. For women with suspected rectovaginal endometriosis, MRI can be utilized following unequivocal rectovaginal physical and transvaginal ultrasound examinations. Associated risks of endometriosis surgery should be thoroughly discussed with the patient by taking a signed informed consent before surgery. In this review, diagnosis and management of rectovaginal or bowel endometriosis are evaluated.

Endometriosis surgery may be conservative for women planning future pregnancy by avoiding surgical trauma to the ovaries that would result with diminished follicular reserve. Direct ablation or excision of endometriotic lesios, removal or ablation of ovarian endometriomas and excision of lesions involving adjacent organs like bowel, appendix, bladder and ureters are surgical methods of conservative management. Definitive treatment is appropriate for patients without future pregnancy desire and includes bilateral oophorectomy with or without removal of the uterus and fallopian tubes by excision of all visible endometriotic lesions within the abdominal cavity. Laparoscopy is superior to laparotomy for surgical management of endometriosis regarding its minimal 
invasive nature, lower complication rates, lower adhesion formation, greater visualization ability during surgery, and rapid recovery period [3]. Patients with severely advanced and infiltrative endometriosis involving bowel and/ or bladder require experienced surgeons to cope with the extent of the disease. DIE is defined as a solid endometriotic mass situated more than $5 \mathrm{~mm}$ deep in the peritoneum rather than endometriotic foci located on the bowel serosa as peritoneal endometriosis [4]. Deeply infitrating endometriosis (DIE) includes rectovaginal nodules, bowel invasion and constriction, bladder invasion, ureteric invasion or compression and nerve entrapment. For pain relief, excision of these lesions with a multidisiplinary approach at the expense of bowel, bladder or ureteric resection and reconstriction is not a uncommon necessity. Rectovaginal or bowel involvement is estimated to be present in 5 to 12 percent of women with endometriosis [5]. The most common site of bowel endometriosis is the rectosigmoid colon [5-8]. Depending upon anatomic location, rectovaginal endometriosis and involvement of the bowel wall proximal to the rectosigmoid colon are two distinct bowel endometriosis entities with different presenting symptoms and management strategies.

Retrograde menstruation is the most popular theory of endometriosis pathogenesis for developement of rectovaginal endometriosis explained as the efflux of the endometrial cells from the fallopian tubes during menstruation that implant in the cul-de-sac which is the most dependent area of the pelvis. Endometrial implants within the abdominal cavity that should be cleared by the immune system under normal circumstances can not be eliminated and cause an inflammatory response and occasionally resulting with a fibrotic nodule under the peritoneum. The other theory about the occurence of rectovaginal endometriosis is coelomic metaplasia of the müllerian rests in the rectovaginal septum [9]. Colorectal endometriosis exhibits multifocality which is explained by infiltration of the large bowel occuring alongside the bowel nerves at a distance from the index palpated DIE lesion. The strong expression of the nerve growth factor tyrosine- kinase A receptor (NGF-TrkA) pathway in deep adenomyotic nodules could explain why this type of lesion infiltrates in richly innervated anatomical sites [10].

\section{Gastrointestinal involvement sites of the disease}

The rectosigmoid colon is the most common affected site of the bowel endometriosis. Among women with a surgically proven diagnosis of endometriosis, the reported prevalence of rectovaginal or bowel involvement ranges from 5 to 25 percent [11]. In a recent observational study including 426 patients with 172 intestinal DIE lesions, the rectum and rectosigmoid colon, sigmoid colon, caecum and ileocaecal jnction, appendix, small bowel and omentum were involved in $65.7 \%, 17.4 \%, 4.1 \%, 6.4 \%, 4.7 \%$ and $1.7 \%$ respectively [12]. Pelvic DIE lesions are more frequently observed in the posterior region of the pelvis and are most often located on the left side unlike abdominal DIE lesions which are most often located in the right side of the abdominal cavity (appendix and ileocaecum junction). During menstruation, menstrua blood accumulates in the pouch of Douglas which is the most dependant portion of the abdomino-pelvic cavity and the anatomic close relationship between the left adnexa ad sigmoid colon impedes pelvic diffusion of the menstrual blood resulting with increased risk for rectosigmoid involvement of DIE. Although being rare; descending colon, transverse colon, or stomach can also be involved with endometriosis [13]. Serosal involvement is more common than (95 percent) and muscularis propria (95 percent), submucosa (38 percent) or mucosa (6 percent) [14]. Colorectal endometriosis treatment is a major challenge for the clinicians that can preclude any surgical intervention when incidentally encountered during a diagnostic laparoscopy. It is preferrable to avoid immediate excision and make a preoperative thorough evaluation to detect the extent of the disease accompanied with obtaining an informed consent from the patient. 


\section{Symptoms and diagnosis}

Women with rectovaginal or bowel endometriosis may present with the usual symptoms of endometriosis like dysmenorrhea, dyspareunia, and infertility and/or with gastrointestinal symptoms like dyschezia, diarrhea, constipation and bloating. Dyschezia and/or rectal bleeding are prominent signs of a bowel neoplasm, inflammatory bowel disease, constipation, hemorrhoids and perirectal abscess. Whenever these symptoms coincide with menstrual bleeding, rectovaginal endometriosis must be remembered to make an accurate differential diagnosis. If a rectovaginal lesion is detected on transvaginal ultrasonography, rectal endoscopic ultrasonography can be used to determine the depth of infiltration and the distance from the anal junction for assessment of the need for and the extent of rectal surgery. A rectovaginal nodule which is not found on both physical examination and transvaginal sonography warrants diagnostic evaluation with MRI.

\section{Medical and surgical management strategies}

Medical treatment of DIE with colorectal involvement results with symptomatic relief without any curative effect on endometriotic foci. Nonsteroidal anti-inflammatory agents, combined oral contraceptives, progestagens, antiprogestagens and GnRH agonists are medical treatment options that can be utilized for medical suppression of the DIE. Surgical management of this severe form of endometriosis is accepted as the primary treatment of DIE which includes laparoscopic segmental excision of the rectum and other colorectal surgical procedures like discoid excision and superficial shaving of the endometriotic lesions. The impact of the surgical treatment modalities on clinical improvement of the symptoms, complications, recurrence and pregnancy rates is not known.

Deep dyspareunia, dyschezia or cyclic rectal bleeding necessitates treatment of rectovaginal endometriosis. Nonspecific gastrointestinal symptoms like rectal bleeding, constipation and bloating warrants treatment of bowel endometriosis also. In the absence of bowel stenosis, medical treatment of rectovaginal or bowel endometriosis that avoids the risks associated with surgery must be the first line choice for treatment of bowel endometriosis. However, women with a rectovaginal nodule are more likely to achieve complete relief of symptoms associated with rectovaginal endometriosis following surgical treatment than with medical therapy, high risk of major postoperative complications stil exists for these women despite a clear indication or surgical treatment.

Randomised controlled studies comparing medical with surgical treatment for rectovaginal or bowel endometriosis are lacking. Although observational studies without presenting the severity of endometriosis revealed that the overall rates of improvement in pain symptoms are about $70 \%$ for either medical or surgical treatment, the effectiveness of medical therapy in treating pelvic pain specifically in women with rectovaginal or bowel endometriosis has not been proven with satisfactory number of studies yet [15]. The recurrence of symptoms following discontinuity of medical treatment, adverse effects of drugs used and time- consuming effect for patients dealing with an infertility problem are disadvantages of medical treatment.

\section{Surgical technique}

Surgical treatment of rectovaginal or bowel endometriosis is guided by the location, size, and depth of infiltration of the endometriotic lesions. Laparoscopic, laparotomic or transvaginal approaches for surgical management of bowelendometriosis have been described. The extent of the bowel surgery depends on the transmural invasion of the endometriotic lesion that can be excised by shaving, superficial excision, full-thickness disc excision or bowel resection followed by anastomosis. Conservative surgery for rectovaginal endometriosis includes dissection of the rectovaginal space, removal of the endometriotic nodule an excision of the influenced area of rectal or vaginal wall when needed. Reich et al. and Donnez et al. [16-18] described the "shaving" technique of 
surgical treatment for rectovaginal endometriosis as dissection of the anterior rectum throughout its area of involvement until the loose tissue of the rectovaginal space is reached prior to excision of visible and palpable deep fibrotic endometriosis even when anterior rectal muscle infiltration is present. Dissection can be carried out by using hydrodissector and the $\mathrm{CO} 2$ laser to completely identify rectum below the lesion before excision of the nodule including an involved portion of the vaginal mucosal tissue. Perirectal visceritis and rectal muscularis involvement can be left in place because these residual lesions remain constant for a long time without causing symptoms to the patients. More invasive surgical treatment methods including bowel resection are not without complications and should not be performed routinely until randomised studies prove that it is more effective than shaving technique. However, bowel occlusion and/ or rectal bleeding with mucosal involvement caused by DIE necessitates resection and anastomosis of the rectosigmoid junction of the bowel.

During surgical treatment of pelvic endometriosis, women without bowel symptoms do not need an additional surgery for bowel endometriosis. Extensive pelvic dissection or bowel resection required for surgical treatment of patients with bowel endometriosis exhibiting clinical symptoms regarding bowel involvement increases patient morbidity. Surgical treatment of rectovaginal endometriosis is associated with major complications like rectovaginal fistulae, anastomotic leakage, pelvic abscess and postoperative bleeding in $3-10 \%$ of patients. The surgery for rectovaginal endometriosis includes exploring and delineating the posterior pelvic anatomy, identifying the ureters bilaterally, developing the pararectal spaces, dissection of the rectum off the posterior vaginal fornix, opening the vaginal fornix when indicated, excision of the endometriotic lesions, assessment of the anterior rectal wall and restoring the anatomy by suturing vagina to the cervix.

\section{Complications and recurrence of bowel endometriosis}

Rectal perforation, fecal peritonitis, ureteral injury and urinary retention are reported complications of rectovaginal endometriosis surgery. Extensive coagulation causing termal amage to the rectal and/ or ureteral wall results with subsequent necrosis and perforation or fistula formation. Incomplete excision of endometriosis is the major cause recurrence following surgery [19]. In one study, recurrence rate of deep endometriosis with excision of the nodule and resection of the posterior vaginal fornix, without resection of the vaginal fornix and bowel resection without resection of the vaginal fornix was $3.7 \%, 16 \%$ and $20 \%$ respectively [20]. Although more prospective studies with large sample sizes and clear definitions of endometriosis recurrence are needed, the authors strongly recommended the shaving technique for the rectum and the resection technique for the involved vaginal part as the first- line therapy for rectovaginal endometriosis. Conversely, Kavallaris et al. [21] revealed that bowel resection and anastomosis method seems to have lower total recurrence rate and visually or histologically proven recurrence rate than shaving and local excision procedures. Studies also exist concluding that rectal segmental resection does not appear to offer better pain control than nodule excision and may result in adverse gastrointestinal symptoms [22]. The treatment modality that should be preferred for an individual patient with bowel endometriosis to decrease recurrence rate merely depends on the degree of bowel involvement rather than utilization of the more extensive surgical method to all patients. The extent and duration of pain relief following surgical treatment of bowel endometriosis can not be measured clearly since outcome measures used by studies have been heterogeneous [23]. 


\section{References}

1. Donnez J, Nisolle M, Smoes P, Gillet N, Beguin S, Casanas-Roux F. Peritoneal endometriosis and "endometriotic" nodules of the rectovaginal septum are two different entities. Fertil Steril 1996; 66: 362-8.

2. Squifflet J, Feger C, Donnez J. Diagnosis and imaging of adenomyotic disease of the retroperitoneal space. Gynecol Obstet Invest 2002; 54: 43-51.

3. Fuller J, Ashar BS, Carey-Corrado J. Trocar associated injuries and fatalities: An analysis of 1399 reports to the FDA. J Minim Invasive Gynecol 2005; 12: 302-7.

4. De Cicco C, Corona R, Schonman R, Mailova K, Ussia A, Koninckx P. Bowel resection for deep endometriosis: A systematic review. BJOG 2011: 285-91.

5. Weed JC, Ray JE. Endometriosis of the bowel. Obstet Gynecol 1987; 69: 727-30.

6. Redwine DB. Ovarian endometriosis: A marker for more extensive pelvic and intestinal disease. Fertil Steril 1999; 72: 310-5.

7. Bailey HR, Ott MT, Hartendorp P. Aggressive surgical management for advanced colorectal endometriosis. Dis Colon Rectum 1994; 37: 747-53.

8. Pereira RM, Zanatta A, Preti CD, de Paula FJ, da Motta EL, Serafini PC. Should the gynecologist perform laparoscopic bowel resection to treat endometriosis? Results over 7 years in 168 patients. J Minim Invasive Gynecol 2009; 16: 472-9.

9. Nisolle M, Donnez J. Peritoneal endometriosis, ovarian endometriosis, and adenomyotic nodules of the rectovaginal septum are three different entities. Fertil Steril 1997; 68: 585-96.

10. Anaf V, Simon P, El Nakadi I, Fayt I, Simonart T, Buxant F, Noel JC. Hyperalgesia, nerve infiltration and nerve growth factor expression in deep adenomyotic nodules, peritoneal and ovarian endometriosis. Hum Reprod 2002; 17: 1895-900.

11. Wills HJ, Reid GD, Cooper MJ, Morgan M. Fertility and pain outcomes following laparoscopic segmental bowel resection for colorectal endometriosis: A review. Aust N Z J Obstet Gynaecol 2008; 48: 292-5.

12. Chapron C, Chopin N, Borghese B, Foulot H, Dousset B, Vacher-Lavenu MC, Vieira M, Hasan W, Bricou A. Deeply infiltrating endometriosis: Pathogenetic implications of the anatomical distribution. Hum Reprod 2006; 21: 1839-45.

13. Hartmann D, Schilling D, Roth SU, Bohrer MH, Riemann JF. [Endometriosis of the transverse colon--a rare localization]. Dtsch Med Wochenschr 2002; 127: 2317-20.

14. Meuleman C, Tomassetti C, D'Hoore A, Van Cleynenbreugel B, Penninckx F, Vergote I, D'Hooghe T. Surgical treatment of deeply infiltrating endometriosis with colorectal involvement. Hum Reprod Update 2011; 17: 311-26.

15. Ferrero S, Camerini G, Ragni N, Venturini PL, Biscaldi E, Remorgida V. Norethisterone acetate in the treatment of colorectal endometriosis: A pilot study. Hum Reprod 2010; 25: 94-100.

16. Reich H, McGlynn F, Salvat J. Laparoscopic treatment of cul-de-sac obliteration secondary to retrocervical deep fibrotic endometriosis. J Reprod Med 1991; 36: 516-22.

17. Donnez J, Nisolle M, Gillerot S, Smets M, Bassil S, Casanas-Roux F. Rectovaginal septum adenomyotic nodules: A series of 500 cases. Br J Obstet Gynaecol 1997; 104: 1014-8.

18. Donnez J, Squifflet J. Laparoscopic excision of deep endometriosis. Obstet Gynecol Clin North Am 2004; 31: 567-80.

19. Vignali M, Bianchi S, Candiani M, Spadaccini G, Oggioni G, Busacca M. Surgical treatment of deep endometriosis and risk of recurrence. J Minim Invasive Gynecol 2005; 12: 508-13.

20. Donnez J, Nisolle M, Squifflet J. Endoscopic management of peritoneal and ovarian endometriosis. In Donnez J, Nisolle M, eds. An atlas of Operative Laparoscopy and Hysteroscopy, 2nd edn. Carnforth, UK: Parthenon Publishing 
2001: 69-76.

21. Kavallaris A, Köhler C, Kühne-Heid R, Schneider A. Histopathological extent of rectal invasion by rectovaginal endometriosis. Hum Reprod 2003; 18: 1323-7.

22. Roman H, Loisel C, Resch B, Tuech JJ, Hochain P, Leroi AM, Marpeau L. Delayed functional outcomes associated with surgical management of deep rectovaginal endometriosis with rectal involvement: Giving patients an informed choice. Hum Reprod 2010; 25: 890-9.

23. Vercellini P, Crosignani PG, Abbiati A, Somigliana E, Viganò P, Fedele L. The effect of surgery for symptomatic endometriosis: The other side of the story. Hum Reprod Update 2009; 15: 177-88. 